\title{
Modelling of Radiological Health Risks from Gold Mine Tailings in Wonderfonteinspruit Catchment Area, South Africa
}

\author{
Manny Mathuthu ${ }^{1}$, Caspah Kamunda ${ }^{1, *}$ and Morgan Madhuku ${ }^{2}$ \\ 1 Center for Applied Radiation Science and Technology, North West University (Mafikeng), P.Bag X2046, \\ Mmabatho 2735, South Africa; Manny.Mathuthu@nwu.ac.za \\ 2 iThemba LABS, National Research Foundation, Private Bag X11, WITS 2050, South Africa; \\ madhuku@tlabs.ac.za \\ * Correspondence: ckamunda@gmail.com; Tel.: +27-73-009-5988
}

Academic Editor: Paul B. Tchounwou

Received: 7 April 2016; Accepted: 3 June 2016; Published: 7 June 2016

\begin{abstract}
Mining is one of the major causes of elevation of naturally-occurring radionuclide material (NORM) concentrations on the Earth's surface. The aim of this study was to evaluate the human risk associated with exposure to NORMs in soils from mine tailings around a gold mine. A broad-energy germanium detector was used to measure activity concentrations of these NORMs in 66 soil samples (56 from five mine tailings and 10 from the control area). The RESidual RADioactivity (RESRAD) OFFSITE modeling program (version 3.1) was then used to estimate the radiation doses and the cancer morbidity risk of uranium-238 $\left({ }^{238} \mathrm{U}\right)$, thorium-232 $\left({ }^{232} \mathrm{Th}\right)$, and potassium- $40\left({ }^{40} \mathrm{~K}\right)$ for a hypothetical resident scenario. According to RESRAD prediction, the maximum total effective dose equivalent (TEDE) during 100 years was found to be $0.0315 \mathrm{mSv} /$ year at year 30, while the maximum total excess cancer morbidity risk for all the pathways was $3.04 \times 10^{-5}$ at year 15. The US Environmental Protection Agency considers acceptable for regulatory purposes a cancer risk in the range of $10^{-6}$ to $10^{-4}$. Therefore, results obtained from RESRAD OFFSITE code has shown that the health risk from gold mine tailings is within acceptable levels according to international standards.
\end{abstract}

Keywords: RESRAD-OFFSITE code; radionuclides; mine tailings; radiation dose; cancer morbidity risk; activity concentration

\section{Introduction}

Naturally-occurring radioactive materials (NORMs) are a common occurrence in our environment since the formation of the Earth. These could be of cosmic, terrestrial, or internal origin [1]. They are generally available in the environment at levels that are not potentially harmful to human health. NORMs account for up to $85 \%$ of the annual dose exposure received by the world population [2]. In certain cases, anthropogenic activities, such as mining, have produced wastes that contain radiation above background levels in the environment, a situation that has been of major concern for radiation protection [3]. Mining can contaminate soils over a large area through radiation exposure and other environmental contaminants [4]. This eventually affects humans through different radiation exposure pathways, either external or internal (i.e., ingestion and inhalation pathways).

NORMs such as ${ }^{238} \mathrm{U},{ }^{232} \mathrm{Th}$, and ${ }^{40} \mathrm{~K}$ provide significant sources of human exposure to ionizing radiation [5]. One of the greatest legacies of South Africa's extensive mineral deposits has been its vast infrastructure and wealth. However, this has left another, more troubling, legacy of environmental contamination from the many years of mining. The epicentre of the problem is in the southwest of Johannesburg where gold mining has been carried out for more than a century in an area called the Wonderfonteinspruit Catchment Area (WCA) [6]. Gold and uranium mining in the WCA has 
taken place from more than 120 mines, with extraction of 43,500 tonnes of gold in one century and 73,000 tonnes of uranium between 1953 and 1995 [6]. This uranium is the principal contaminant of concern within the gold mining areas of the WCA. It is reported that gold-bearing ores may contain almost ten times the amount of uranium than gold [7]. It is believed that the uranium content in many gold mine tailings exceeds the exclusion limit for regulation by the National Nuclear Regulator [8]. With mine tailings littered everywhere within the WCA, this produces large quantities of uranium in the area, inducing a radiological burden to man and possible damage to agricultural land and water resources.

Although a number of radiological studies have been carried out in the WCA, very little concrete data is available for the gold mining area in question. The extent of the possible risk of these radionuclides to the health of the population in the study area has also not been fully documented. As a result, radiological measurements were conducted on gold mine tailings in order to estimate the human risk caused by these radionuclides for a hypothetical resident scenario with the help of the RESidual RADioactivity (RESRAD) computer program (Argonne, Lemont, IL, USA). Exposure scenarios are patterns of human activity that can affect the release of radioactivity from the contaminated zone and the amount of exposure received at the exposure location. The hypothetical resident scenario includes all environmental pathways for on-site or near-site exposure that results in the highest predicted lifetime dose [9].

\section{Materials and Methods}

\subsection{The Study Area}

The study area is located in the West Wits line (Far West Rand) Goldfield of the lower central part of Wonderfonteinspruit Catchment Area (WCA) and covers an area of approximately $86 \mathrm{~km}^{2}$. It lies between $26^{\circ} 18^{\prime} \mathrm{S}$ and $26^{\circ} 26^{\prime} \mathrm{S}$ latitude and $27^{\circ} 23^{\prime} \mathrm{E}-27^{\circ} 31^{\prime} \mathrm{E}$ longitude. Gold exploration in the area dates back to 1898 and mining progressed from 1945 until the present [10]. Geologically, the area is created mainly from sedimentary rocks that consist of banded ironstones, quartzites, tillites, conglomerates, mudstones, and some marine lava deposits [11]. Mining activities are engaged in both deep-level (500 m-4000 m), high-grade underground mining as well as low-grade, surface rock dump mining.

The gold mine has five mine tailings that have been accumulated throughout the operating history of the mine. The topography of the area is relatively flat and the vegetation is largely grassland. The soils are generally sandy loam with livestock farming widespread in the surrounding area [12]. The climate is temperate, with temperatures averaging $24^{\circ} \mathrm{C}$ in summer and $13^{\circ} \mathrm{C}$ in winter, occasionally dipping below the freezing point. Annual rainfall is about $750 \mathrm{~mm}$ [10]. The study area has a population of more than 14,000 . There are also some informal settlements residing close to the mine tailings.

\subsection{Sampling and Measurement of Activity Concentrations}

A total of 66 soil samples, 56 from five mine tailings in the study area and 10 from the control area, were randomly collected with a coring tool at a depth of $5 \mathrm{~cm}$. A Global Positioning System (GPS) receiver was used to locate the sampling points. These soil samples were then packaged in plastic bags carrying identification marks according to the IAEA [13]. They were then taken to the laboratory for preparation before analysis. At the laboratory, each sample was dried, crushed into fine power, and mixed to form a homogenous sample. The samples were then transferred and sealed into plastic Marinelli beakers for about four weeks to attain secular equilibrium with some progenies of ${ }^{238} \mathrm{U}$ and ${ }^{232} \mathrm{Th}$.

Measurement of activity concentrations in soil samples was carried out by means of a broad-energy germanium (BEGe) detector (BE6530) manufactured by Canberra Industries (Meriden, CT, USA). It has a relative efficiency of $60 \%$ and a resolution of $2.0 \mathrm{keV}$ for $1332 \mathrm{keV}$ gamma ray emission of ${ }^{60} \mathrm{Co}$ [14]. 
Energy and efficiency calibrations of the gamma spectrometer were also performed before sample measurement. The activity concentrations of ${ }^{238} \mathrm{U},{ }^{232} \mathrm{Th}$, and ${ }^{40} \mathrm{~K}$ were calculated based on the weighted average values of their respective daughter products in secular equilibrium. In this analysis, ${ }^{238} \mathrm{U}$ was considered as it accounted for its daughter products, such as ${ }^{226} \mathrm{Ra}$.

At the laboratory, the soil samples were first spread out on a plastic sheet and allowed to air dry for 2-3 days. The soil samples were then heated in an electric oven at $110{ }^{\circ} \mathrm{C}$ for up to $24 \mathrm{~h}$ to remove moisture content and, thereafter, put in an electric furnace at $350{ }^{\circ} \mathrm{C}$ for $48 \mathrm{~h}$ to burn the plant remains. The samples were then grinded and sieved with a $2 \mathrm{~mm}$ stainless steel mesh. The samples, with known masses, were then packed and sealed in plastic Marinelli beakers for 28 days in order to establish a secular equilibrium among some progenies of ${ }^{238} \mathrm{U}$ and ${ }^{232} \mathrm{Th}$ series. To measure the activity concentrations in soil samples, Marinelli beakers were then placed on top of the detector that was lead shielded to avoid background radiation. The measuring process and analysis of spectra was done using GENIE 2000 software. More information on measurement procedure can be found in our previous paper [10].

\subsection{RESRAD-OFFSITE Computer Code}

Environmental issues are quite challenging to solve because of the complex relationships among the many variables that exist [15]. Modelling, therefore, plays a pivotal role in this regard. One of the most frequently used modelling software is called RESRAD code. RESRAD was developed by the Argonne National Laboratory under the U.S. Department of Energy and the U.S. Nuclear Regulatory Commission as a multifunctional tool to assist in developing criteria for evaluating human radiation doses and risks associated with exposure to radiological contamination [9]. In this evaluation procedure, RESRAD uses U.S. Federal Guidance Report No. 12 [16] and the ICRP-38 radionuclide database. The radionuclide database also accounts for ingrowth of daughters from initially-present parent radionuclides [9]. RESRAD allows users to specify the features of their site and to predict the dose received by an individual at any time up to 100,000 years. It models a site through the use of more than 150 variables. These parameters each has a default value assigned by the developers at Argonne, but can be changed to suit site-specific needs [17].

RESRAD-OFFSITE is an extension of the RESRAD-ONSITE computer code that was developed to estimate the radiological consequences to individuals located onsite or outside the area of primary contamination. The total primary area contaminated by the mine tailings was estimated to be $16 \mathrm{~km}^{2}$ and is assumed to be a uniformly distributed layer of soil. The code considers the release of radionuclides from the primary contamination source to the atmosphere, to surface runoff, and to groundwater. It calculates the radiation dose and excess cancer risk with the predicted radionuclide concentrations in the environment [18]. In this study, five exposure pathways were considered in RESRAD-OFFSITE: direct exposure from contamination in soil, inhalation of dust/radon, ingestion of plant foods (crops), ingestion of water (borehole water), and incidental ingestion of soil. By selecting the different pathways, RESRAD-OFFSITE can be used to model the resident exposure scenario [19].

\subsection{Transport Pathways Associated with NORMs in the Study Area}

Major mechanisms of radionuclides transport from potential primary contamination mining sources are the atmosphere, ground water sources, and surface water bodies. Gold mine tailings in the study area constitute a major source of NORMs pollution to the environment. Other sources are rock dumps, processing plants, return-water dams, storm water drainage systems, settling ponds, and evaporation dams. Radionuclides from these sources can either be leached into the underlying ground water aquifers or dissolved and drained through runoff into surface water bodies, thereby contaminating water sources.

In some instances, fissure water is treated in water purification plants and used for human consumption. Fissure water comes from underground mine workings and can be a source of contamination if it is in contact with oxidized ore. Water used in mining processes is called process 
water and usually contains dissolved pollutants. If it is discharged into the environment through either evaporation, seepage, or run-off, it can eventually affect humans. Storm water run-off from areas such as ore piles, gold plants, mine tailings, rock dumps, and return dams can contaminate the environment. In addition, these radionuclides from the primary sources can also be transported to humans via the atmosphere, either as windblown dust or radon. Figure 1 shows the Conceptual Site Model for the Study Area.

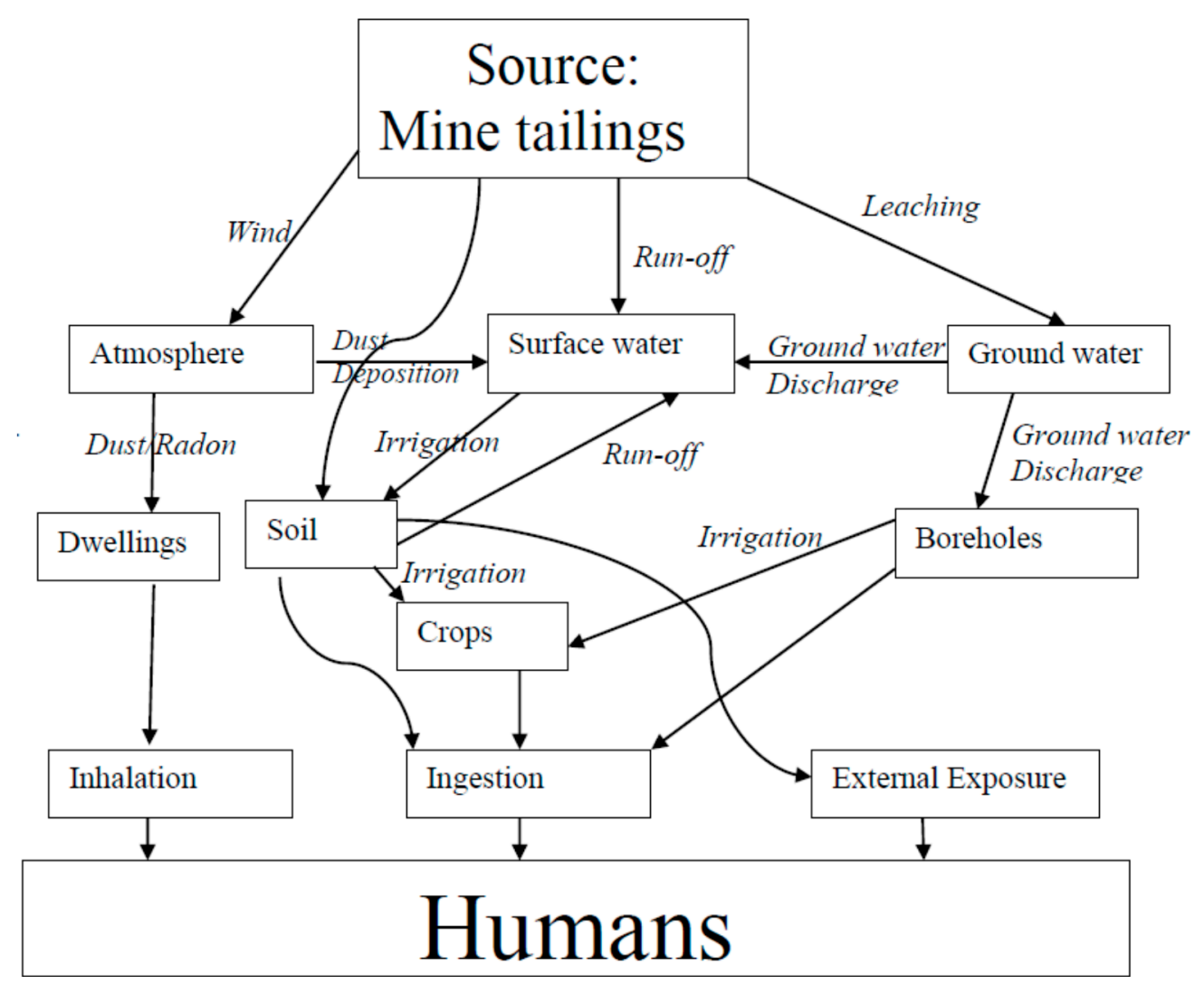

Figure 1. Conceptual site model for the study area.

\subsection{Input Parameters and Scenario Description for RESRAD-OFFSITE Code}

For the study area, a number of parameters were considered as inputs to the RESRAD-OFFSITE code. The resident scenario was chosen as the critical receptor in this risk assessment. The parameter values were carefully selected to achieve a more realistic estimation of the dose or risk. Where necessary, site-specific parameters replaced default parameters [20].

Input parameters to the model included the measured activity concentrations of ${ }^{238} \mathrm{U},{ }^{232} \mathrm{Th},{ }^{40} \mathrm{~K}$, and meteorological data (annual wind speed and direction). Hydrogeological parameters for the various zones were also taken into consideration. These included hydraulic conductivity and density of the soil. Some hydrological parameters, such as total porosity, field capacity, irrigation rate, erosion rate, precipitation rate, runoff coefficient, and soil-specific exponential parameters were also estimated based on the condition of the study area [20]. The area and thickness of the different zones were also taken into account.

The main exposures in this scenario included direct exposure to the radionuclides in soil, inhalation of dust, and ingestion of contaminated vegetables, water, and soil. Dietary information on vegetables, water, and soil were also considered through regulatory guidelines set by the National Nuclear Regulator [21]. Inhalation rate, soil ingestion rate, and the distribution coefficient for radionuclides in the study area were also taken into account according to guidelines [21]. The RESRAD 
library of radionuclides was then used in this assessment. A summary of the most relevant data used for the risk assessment is shown in Table 1.

Table 1. Input Parameters for the RESRAD-OFFSITE code.

\begin{tabular}{|c|c|c|}
\hline Parameter & Value & Description and/or Reference \\
\hline $\begin{array}{l}\text { Average activity concentrations of }{ }^{238} \mathrm{U},{ }^{232} \mathrm{Th}, \\
\text { and }{ }^{40} \mathrm{~K}\end{array}$ & Table 2 & $\begin{array}{l}\text { The values were based on } \\
\text { measurements. }\end{array}$ \\
\hline Area of contaminated zone $\left(\mathrm{m}^{2}\right)$ & $16,000,000$ & $\begin{array}{l}\text { This was the average estimated } \\
\text { over the whole area. }\end{array}$ \\
\hline Thickness of contaminated zone (m) & 0.05 & $\begin{array}{l}\text { This was the average estimated } \\
\text { over the whole area. }\end{array}$ \\
\hline Cover depth (m) & 0 & $\begin{array}{l}\text { There was no cover depth for } \\
\text { the radionuclides }\end{array}$ \\
\hline Density of contaminated zone $\left(\mathrm{g} / \mathrm{m}^{3}\right)$ & 1.44 & For sandy loam soil [20]. \\
\hline Erosion rate for contaminated zone (m/year) & 0.001 & RESRAD default value [20]. \\
\hline Total porosity for contaminated zone & 0.43 & $\begin{array}{l}\text { For sedimentary material which } \\
\text { is sand fine [20]. }\end{array}$ \\
\hline Field capacity for contaminated zone & 0.2 & RESRAD default value [20]. \\
\hline $\begin{array}{l}\text { Hydraulic conductivity of contaminated } \\
\text { zone }(\mathrm{m} / \text { year })\end{array}$ & 1090 & For sandy loam soil [20]. \\
\hline Soil-specific exponential b parameter & 4.9 & For sandy loam soil [20]. \\
\hline Average annual wind speed (m/s) & 5 & For the area [22]. \\
\hline Evapotranspiration coefficient & 0.5 & RESRAD default value [21]. \\
\hline Precipitation rate (m/year) & 1 & The area is relatively humid [21]. \\
\hline Irrigation rate & 0.2 & RESRAD default value [21]. \\
\hline Runoff coefficient & 0.65 & $\begin{array}{l}\text { For moderately steep, } \\
\text { residential area. }\end{array}$ \\
\hline Inhalation rate $\left(\mathrm{m}^{3} /\right.$ year $)$ & 8059.2 & For South Africa [21]. \\
\hline Exposure duration (year) & 30 & RESRAD default value [20]. \\
\hline Fraction of time spent onsite & $\begin{array}{c}0 \\
0.1\end{array}$ & For South Africa [21]. \\
\hline Fraction of time spent offsite & $\begin{array}{l}0.8 \\
0.1\end{array}$ & For South Africa [21]. \\
\hline Soil ingestion rate (g/year) & 37 & For South Africa [21]. \\
\hline Leach rate & 0 & RESRAD default value [20]. \\
\hline Water drinking rate (L/year) & 600 & For South Africa [21]. \\
\hline Distribution coefficient $\left(\mathrm{K}_{\mathrm{d}}\right)$-uranium $\left(\mathrm{cm}^{3} / \mathrm{g}\right)$ & 200 & For South Africa [21]. \\
\hline Distribution coefficient $\left(\mathrm{K}_{\mathrm{d}}\right)$-thorium $\left(\mathrm{cm}^{3} / \mathrm{g}\right)$ & 60,000 & RESRAD default value [20]. \\
\hline Distribution coefficient $\left(\mathrm{K}_{\mathrm{d}}\right)$-potassium $\left(\mathrm{cm}^{3} / \mathrm{g}\right)$ & 5.5 & RESRAD default value [20]. \\
\hline
\end{tabular}

\section{Results and Discussion}

\subsection{NORM Activities Concentration in Soil}

Table 2 shows the average activity concentrations of radionuclides with uncertainties for soil samples from the mine tailings and from the control area derived from our earlier paper [10]. These were used as input parameters in RESRAD-OFFSITE code to calculate the radiation dose, as well as the excess cancer morbidity risk. 
Table 2. Activity concentrations of ${ }^{238} \mathrm{U},{ }^{232} \mathrm{Th}$, and ${ }^{40} \mathrm{~K}$ for soil samples from the mine tailings [10].

\begin{tabular}{|c|c|c|c|c|c|}
\hline \multirow{2}{*}{ Location } & \multirow{2}{*}{$\begin{array}{c}\text { No. of } \\
\text { Samples }\end{array}$} & \multirow{2}{*}{ Parameter } & \multicolumn{3}{|c|}{ Activity Concentrations $\left(\mathrm{Bq} \cdot \mathrm{kg}^{-1}\right)$} \\
\hline & & & ${ }^{238} \mathrm{U}$ & ${ }^{232} \mathrm{Th}$ & ${ }^{40} \mathrm{~K}$ \\
\hline \multirow{3}{*}{ Control area } & \multirow{3}{*}{10} & Average & $17.0 \pm 0.4$ & $22.2 \pm 0.5$ & $496.8 \pm 15.2$ \\
\hline & & Min & $12.5 \pm 0.3$ & $16.6 \pm 0.4$ & $424.3 \pm 13.0$ \\
\hline & & Max & $23.6 \pm 0.5$ & $30.4 \pm 0.6$ & $648.4 \pm 19.8$ \\
\hline \multirow{3}{*}{ Tailings one } & \multirow{3}{*}{11} & Average & $733.4 \pm 12.7$ & $41.3 \pm 0.9$ & $339.9 \pm 10.7$ \\
\hline & & Min & $304.4 \pm 5.4$ & $36.5 \pm 0.8$ & $271.5 \pm 9.0$ \\
\hline & & Max & $1243.4 \pm 21.6$ & $54.5 \pm 1.2$ & $468.4 \pm 14.6$ \\
\hline \multirow{3}{*}{ Tailings two } & \multirow{3}{*}{13} & Average & $794.9 \pm 13.8$ & $44.9 \pm 1.0$ & $460.7 \pm 14.4$ \\
\hline & & Min & $616.6 \pm 10.7$ & $38.4 \pm 0.9$ & $226.5 \pm 7.8$ \\
\hline & & Max & $1391.8 \pm 24.1$ & $49.5 \pm 1.1$ & $681.9 \pm 21.0$ \\
\hline \multirow{3}{*}{ Tailings three } & \multirow{3}{*}{8} & Average & $1556.2 \pm 27.0$ & $59.0 \pm 1.3$ & $354.3 \pm 11.4$ \\
\hline & & Min & $390.9 \pm 6.8$ & $22.3 \pm 0.6$ & $233.8 \pm 7.5$ \\
\hline & & Max & $2668.9 \pm 46.2$ & $89.7 \pm 1.9$ & $497.1 \pm 15.6$ \\
\hline \multirow{3}{*}{ Tailings four } & \multirow{3}{*}{12} & Average & $232.0 \pm 4.1$ & $33.2 \pm 0.8$ & $489.5 \pm 14.1$ \\
\hline & & Min & $87.2 \pm 1.6$ & $20.5 \pm 0.6$ & $257.9 \pm 8.3$ \\
\hline & & Max & $618.2 \pm 10.8$ & $49.1 \pm 1.1$ & $781.0 \pm 23.9$ \\
\hline \multirow{3}{*}{ Tailings five } & \multirow{3}{*}{12} & Average & $609.7 \pm 10.6$ & $41.1 \pm 0.9$ & $490.7 \pm 15.2$ \\
\hline & & Min & $236.1 \pm 4.2$ & $25.3 \pm 0.6$ & $281.2 \pm 8.8$ \\
\hline & & Max & $2054.7 \pm 35.6$ & $67.1 \pm 1.4$ & $574.9 \pm 17.7$ \\
\hline \multicolumn{3}{|c|}{ Average all tailings } & $485.3 \pm 13.7$ & $43.9 \pm 1.0$ & $427.0 \pm 13.1$ \\
\hline
\end{tabular}

\subsection{Radiation Doses Using RESRAD-OFFSITE Computer Code}

The total effective dose equivalent ( $\mathrm{mSv} /$ year) from gold mine tailings and the control area for all of the pathways summed over a duration of 100 years were calculated as shown in Tables 3 and 4, respectively. According to RESRAD, the maximum TEDE from gold mine tailings during 100 years was found to be $0.0315 \mathrm{mSv}$ /year at year 30 compared to a value of $0.0148 \mathrm{mSv} /$ year from the control area. In both areas, ${ }^{232} \mathrm{Th}$ contributed the most to TEDE, while ${ }^{40} \mathrm{~K}$ and ${ }^{238} \mathrm{U}$ had lesser effect.

Table 3. Total effective dose equivalent (mSv/year) from gold mine tailings for all the pathways summed over a duration of 100 years.

\begin{tabular}{ccccc}
\hline & \multicolumn{3}{c}{ Total Effective Dose Equivalent (mSv/Year) } \\
\cline { 2 - 4 } Year & \multicolumn{3}{c}{ Nuclides } & Total \\
\cline { 2 - 4 } & ${ }^{40} \mathbf{K}$ & ${ }^{232} \mathbf{T h}$ & ${ }^{238} \mathbf{U}$ & \\
\hline 0 & $1.20 \times 10^{-2}$ & $2.29 \times 10^{-3}$ & $4.53 \times 10^{-3}$ & $1.88 \times 10^{-2}$ \\
5 & $4.43 \times 10^{-4}$ & $1.37 \times 10^{-2}$ & $4.12 \times 10^{-3}$ & $1.83 \times 10^{-2}$ \\
10 & $1.18 \times 10^{-5}$ & $2.25 \times 10^{-2}$ & $3.72 \times 10^{-3}$ & $2.62 \times 10^{-2}$ \\
15 & $4.35 \times 10^{-7}$ & $2.63 \times 10^{-2}$ & $3.39 \times 10^{-3}$ & $2.96 \times 10^{-2}$ \\
20 & $1.61 \times 10^{-8}$ & $2.79 \times 10^{-2}$ & $3.08 \times 10^{-3}$ & $3.10 \times 10^{-2}$ \\
25 & $5.94 \times 10^{-10}$ & $2.86 \times 10^{-2}$ & $2.81 \times 10^{-3}$ & $3.14 \times 10^{-2}$ \\
30 & $1.58 \times 10^{-11}$ & $2.89 \times 10^{-2}$ & $2.53 \times 10^{-3}$ & $3.15 \times 10^{-2}$ \\
35 & $5.84 \times 10^{-13}$ & $2.90 \times 10^{-2}$ & $2.31 \times 10^{-3}$ & $3.14 \times 10^{-2}$ \\
40 & $2.16 \times 10^{-14}$ & $2.91 \times 10^{-2}$ & $2.10 \times 10^{-3}$ & $3.12 \times 10^{-2}$ \\
45 & $7.98 \times 10^{-16}$ & $2.91 \times 10^{-2}$ & $1.91 \times 10^{-3}$ & $3.10 \times 10^{-2}$ \\
50 & $2.95 \times 10^{-17}$ & $2.91 \times 10^{-2}$ & $1.74 \times 10^{-3}$ & $3.08 \times 10^{-2}$ \\
55 & $7.83 \times 10^{-19}$ & $2.90 \times 10^{-2}$ & $1.57 \times 10^{-3}$ & $3.06 \times 10^{-2}$ \\
60 & $2.90 \times 10^{-20}$ & $2.90 \times 10^{-2}$ & $1.43 \times 10^{-3}$ & $3.05 \times 10^{-2}$ \\
65 & $1.07 \times 10^{-21}$ & $2.90 \times 10^{-2}$ & $1.30 \times 10^{-3}$ & $3.03 \times 10^{-2}$ \\
70 & $3.96 \times 10^{-23}$ & $2.90 \times 10^{-2}$ & $1.18 \times 10^{-3}$ & $3.02 \times 10^{-2}$ \\
75 & $1.05 \times 10^{-24}$ & $2.90 \times 10^{-2}$ & $1.07 \times 10^{-3}$ & $3.00 \times 10^{-2}$ \\
80 & $3.89 \times 10^{-26}$ & $2.89 \times 10^{-2}$ & $9.73 \times 10^{-4}$ & $2.99 \times 10^{-2}$ \\
85 & $1.44 \times 10^{-27}$ & $2.89 \times 10^{-2}$ & $8.86 \times 10^{-4}$ & $2.98 \times 10^{-2}$ \\
90 & $5.31 \times 10^{-29}$ & $2.89 \times 10^{-2}$ & $8.07 \times 10^{-4}$ & $2.97 \times 10^{-2}$ \\
95 & $1.41 \times 10^{-30}$ & $2.89 \times 10^{-2}$ & $7.28 \times 10^{-4}$ & $2.96 \times 10^{-2}$ \\
100 & $5.22 \times 10^{-32}$ & $2.88 \times 10^{-2}$ & $6.63 \times 10^{-4}$ & $2.95 \times 10^{-2}$ \\
\hline
\end{tabular}


Table 4. Total effective dose equivalent (mSv/year) from the control area for all the pathways summed over a duration of 100 years.

\begin{tabular}{ccccc}
\hline & \multicolumn{3}{c}{ Total Effective Dose Equivalent (mSv/Year) } \\
\cline { 2 - 4 } Year & \multicolumn{3}{c}{ Nuclides } & \multirow{2}{*}{ Total } \\
\cline { 2 - 4 } & ${ }^{40} \mathbf{K}$ & ${ }^{232} \mathbf{T h}$ & ${ }^{238} \mathbf{U}$ & \\
\hline 0 & $1.39 \times 10^{-2}$ & $1.16 \times 10^{-3}$ & $1.60 \times 10^{-4}$ & $1.53 \times 10^{-2}$ \\
5 & $5.15 \times 10^{-4}$ & $6.92 \times 10^{-3}$ & $1.60 \times 10^{-4}$ & $7.60 \times 10^{-3}$ \\
10 & $1.37 \times 10^{-5}$ & $1.14 \times 10^{-2}$ & $1.60 \times 10^{-4}$ & $1.15 \times 10^{-2}$ \\
15 & $5.06 \times 10^{-7}$ & $1.33 \times 10^{-2}$ & $1.60 \times 10^{-4}$ & $1.34 \times 10^{-2}$ \\
20 & $1.87 \times 10^{-8}$ & $1.41 \times 10^{-2}$ & $1.60 \times 10^{-4}$ & $1.43 \times 10^{-2}$ \\
25 & $6.91 \times 10^{-10}$ & $1.45 \times 10^{-2}$ & $1.59 \times 10^{-4}$ & $1.46 \times 10^{-2}$ \\
30 & $1.84 \times 10^{-11}$ & $1.46 \times 10^{-2}$ & $1.59 \times 10^{-4}$ & $1.48 \times 10^{-2}$ \\
35 & $6.79 \times 10^{-13}$ & $1.47 \times 10^{-2}$ & $1.59 \times 10^{-4}$ & $1.48 \times 10^{-2}$ \\
40 & $2.51 \times 10^{-14}$ & $1.47 \times 10^{-2}$ & $1.59 \times 10^{-4}$ & $1.49 \times 10^{-2}$ \\
45 & $9.28 \times 10^{-16}$ & $1.47 \times 10^{-2}$ & $1.59 \times 10^{-4}$ & $1.49 \times 10^{-2}$ \\
50 & $3.43 \times 10^{-17}$ & $1.47 \times 10^{-2}$ & $1.59 \times 10^{-4}$ & $1.49 \times 10^{-2}$ \\
55 & $9.12 \times 10^{-19}$ & $1.47 \times 10^{-2}$ & $1.59 \times 10^{-4}$ & $1.48 \times 10^{-2}$ \\
60 & $3.37 \times 10^{-20}$ & $1.47 \times 10^{-2}$ & $1.58 \times 10^{-4}$ & $1.48 \times 10^{-2}$ \\
65 & $1.25 \times 10^{-21}$ & $1.47 \times 10^{-2}$ & $1.58 \times 10^{-4}$ & $1.48 \times 10^{-2}$ \\
70 & $4.60 \times 10^{-23}$ & $1.47 \times 10^{-2}$ & $1.58 \times 10^{-4}$ & $1.48 \times 10^{-2}$ \\
75 & $1.22 \times 10^{-24}$ & $1.46 \times 10^{-2}$ & $1.58 \times 10^{-4}$ & $1.48 \times 10^{-2}$ \\
80 & $4.52 \times 10^{-26}$ & $1.46 \times 10^{-2}$ & $1.58 \times 10^{-4}$ & $1.48 \times 10^{-2}$ \\
85 & $1.67 \times 10^{-27}$ & $1.46 \times 10^{-2}$ & $1.58 \times 10^{-4}$ & $1.48 \times 10^{-2}$ \\
90 & $6.18 \times 10^{-29}$ & $1.46 \times 10^{-2}$ & $1.58 \times 10^{-4}$ & $1.48 \times 10^{-2}$ \\
95 & $1.64 \times 10^{-30}$ & $1.46 \times 10^{-2}$ & $1.57 \times 10^{-4}$ & $1.48 \times 10^{-2}$ \\
100 & $6.07 \times 10^{-32}$ & $1.46 \times 10^{-2}$ & $1.57 \times 10^{-4}$ & $1.47 \times 10^{-2}$ \\
\hline
\end{tabular}

RESRAD-OFFSITE simulation has also shown that the water-independent pathway is the most significant pathway. In this pathway, most of the annual effective dose equivalent is caused by direct radiation from soil followed by radon (direct and airborne), then inhalation, followed by soil ingestion (direct and airborne). Figure 2 shows the radiation doses over a duration of 100 years following contamination.

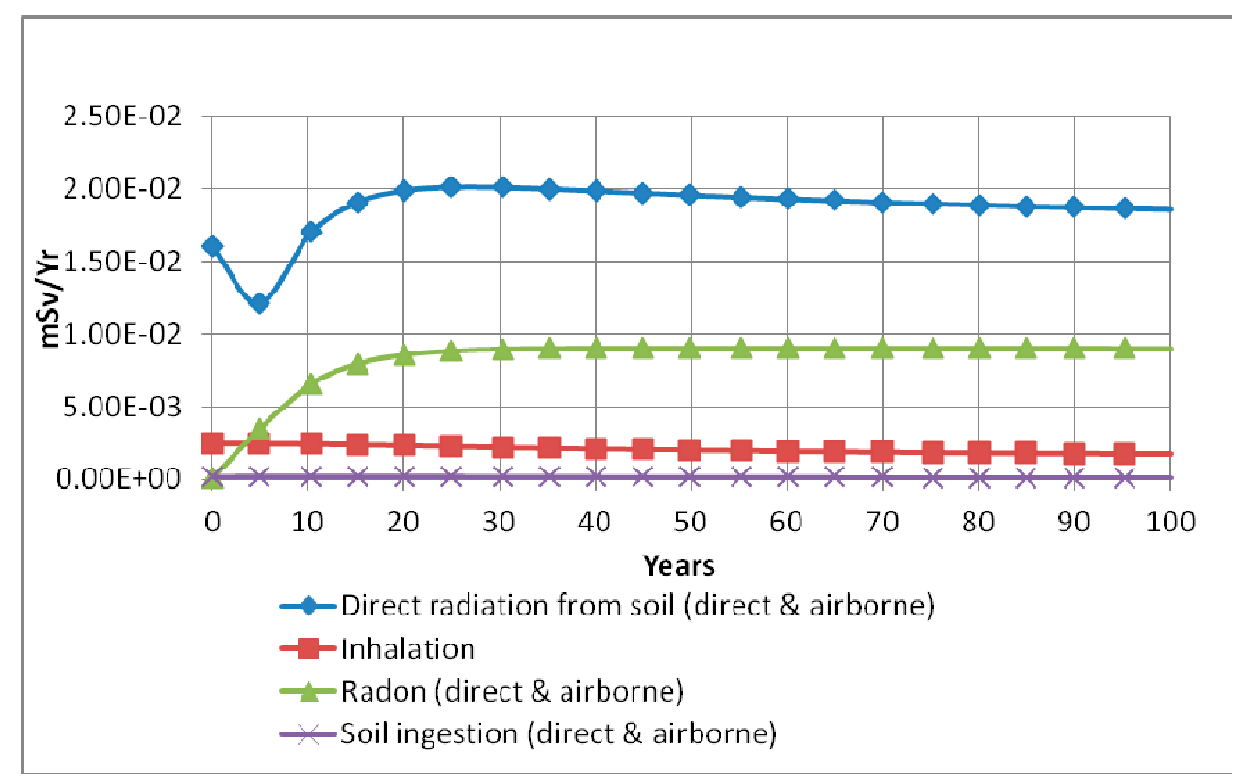

Figure 2. Total effective dose equivalent from all radionuclides summed based on component pathways over a duration of 100 years. 


\subsection{Excess Cancer Morbidity Risk Using RESRAD-OFFSITE Computer Code}

The results of the radiation doses for the gold mine tailings and control area presented in Tables 3 and 4 were used by RESRAD-OFFSITE computer code to calculate the excess cancer morbidity risks from for all of the pathways summed over a duration of 100 years. Figure 3 clearly shows the excess cancer morbidity risk from gold mine tailings. This was obtained by subtracting the cancer risk of the control area (assumed to be background) from that of mine tailings. The maximum total excess cancer morbidity risk from gold mine tailings was found to be $3.04 \times 10^{-5}$ at year 15 . This progressively decreased to $2.68 \times 10^{-5}$ at year 100. ${ }^{232}$ Th was driving the risk effect followed by ${ }^{238} \mathrm{U}$, and then lastly ${ }^{40} \mathrm{~K}$. The US Environmental Protection Agency considers acceptable, for regulatory purposes, a cancer risk in the range of $10^{-6}$ to $10^{-4}$ [23]. Therefore, results obtained from the RESRAD-OFFSITE code has shown that the health risk from gold mine tailings is within acceptable levels according to international standards.

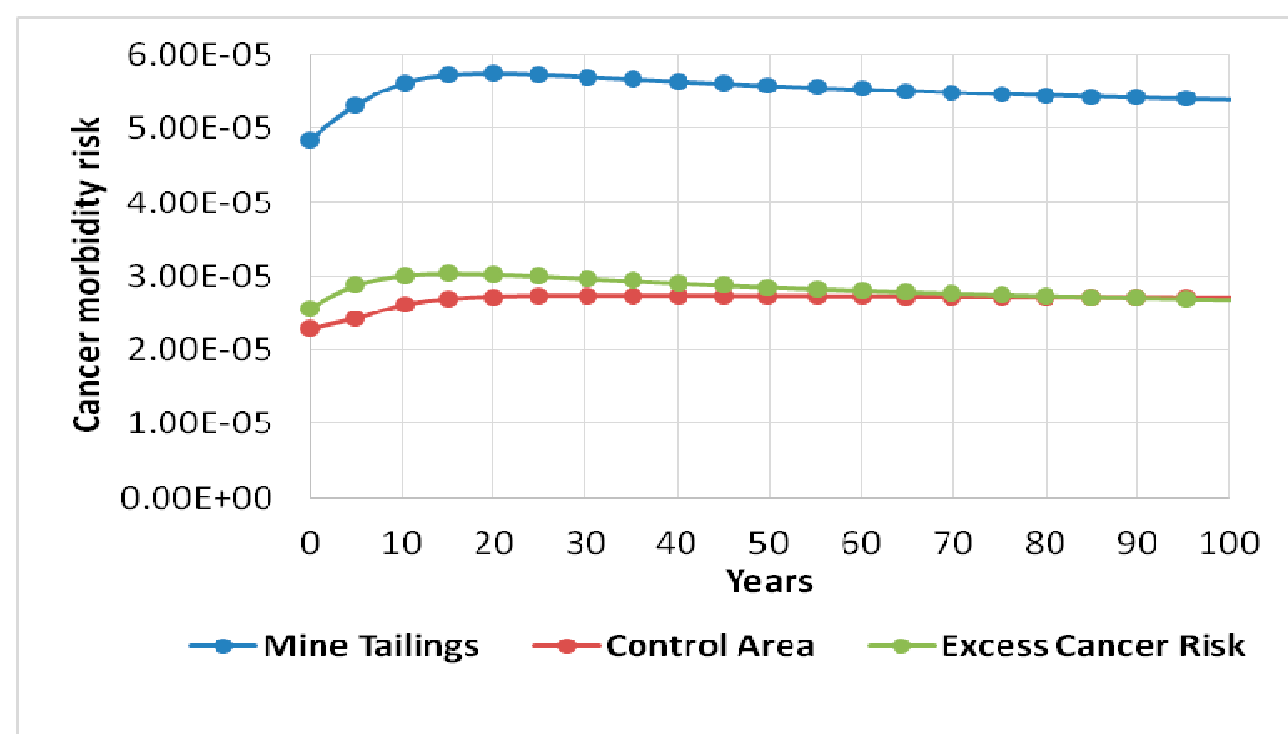

Figure 3. Excess morbidity cancer risks from the gold mine tailings as a result of all radionuclides summed with all pathways summed for the first 100 years.

\subsection{Sensitivity Analysis}

Single parameter RESRAD sensitivity analysis on some of the most important parameters was undertaken in order to evaluate the extent of their effect on cancer morbidity risk. These were contamination zone thickness, cover depth, occupancy factor, inhalation rate, soil ingestion rate, and water drinking rate. It was discovered that variations on occupancy factor, inhalation rate, soil ingestion rate, and water drinking rate had insignificant effects on the cancer morbidity risk. However, contamination zone thickness and cover depth affected the results in a significant way. Figures 4 and 5 show results of the sensitivity run on contamination zone thickness and cover depth, respectively. Figure 4 shows that varying the thickness of the contamination zone from $2.5 \mathrm{~cm}$ to $10 \mathrm{~cm}$ increased the cancer morbidity risk by a maximum of approximately $26 \%$. RESRAD sensitivity analysis has also shown that varying the cover depth from $0 \mathrm{~cm}$ to $1.5 \mathrm{~cm}$ causes a maximum reduction in cancer morbidity risk of about 13\%. This is clearly illustrated in Figure 5. 


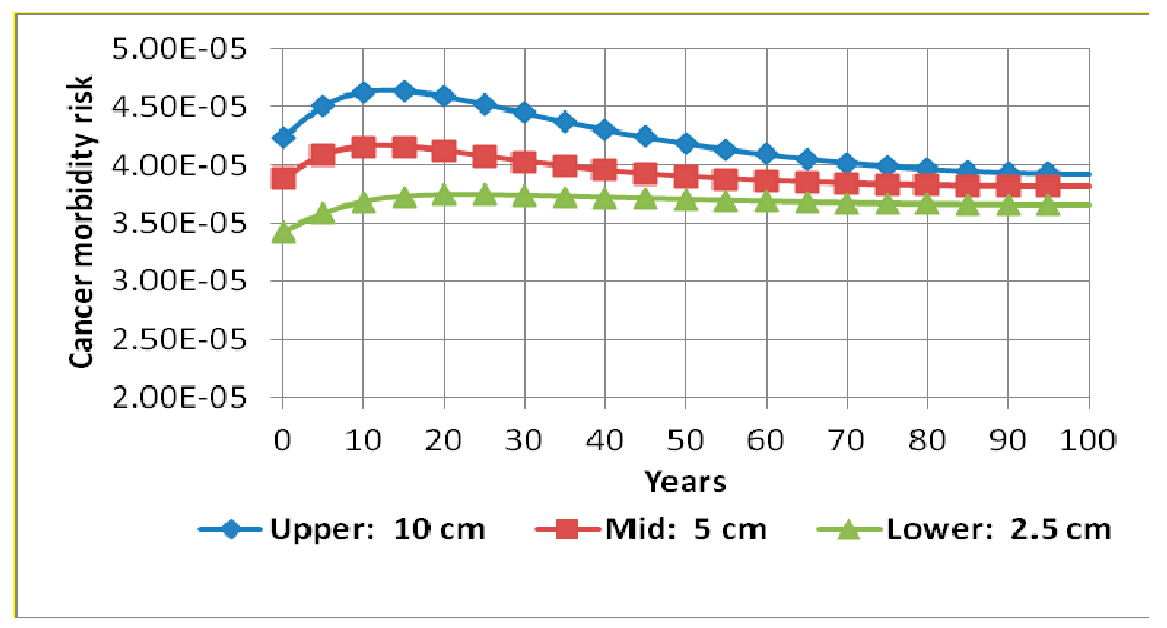

Figure 4. Cancer morbidity risk from all radionuclides $\left({ }^{238} \mathrm{U},{ }^{232} \mathrm{Th}\right.$, and $\left.{ }^{40} \mathrm{~K}\right)$ and all pathways summed during 100 years with sensitivity analysis on contamination zone thickness.

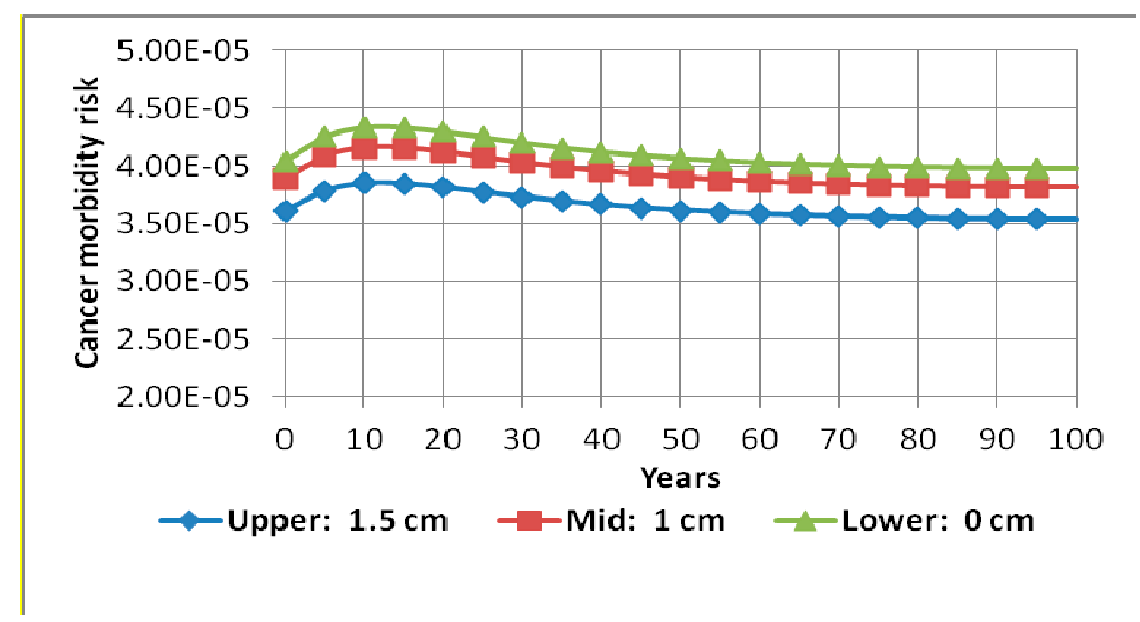

Figure 5. Cancer morbidity risk from all radionuclides $\left({ }^{238} \mathrm{U},{ }^{232} \mathrm{Th}\right.$, and $\left.{ }^{40} \mathrm{~K}\right)$ and all pathways summed during 100 years with sensitivity analysis on cover depth.

\section{Conclusions}

This study has evaluated the human risk associated with exposure to NORMs in soils from mine tailings around a gold mine using the RESRAD-OFFSITE code. The total effective dose equivalent (TEDE) from all nuclides was found to range from $1.88 \times 10^{-2}$ to $3.15 \times 10^{-2}$. Results from the study has shown that the water-independent pathway is the most significant pathway contributing to the dose. In this pathway, most of the TEDE is caused by direct radiation from the soil, followed by radon (direct and airborne). The total excess cancer morbidity risk estimated from the model ranged from $2.57 \times 10^{-5}$ to $3.04 \times 10^{-5}$. It has also be noted from the simulation that ${ }^{232} \mathrm{Th}$ has a significant contribution to the radiation dose, as well as the excess cancer morbidity risk, compared to ${ }^{238} \mathrm{U}$ and ${ }^{40} \mathrm{~K}$. This may be attributed to higher dose conversion factors associated with ${ }^{232} \mathrm{Th}$ compared to the other two. From the findings of this research it can, therefore, be concluded that gold mine tailings from the study area had a negligible risk in accordance with international guidelines on radiation safety.

Acknowledgments: Authors would like to acknowledge the support they have received from Department of Geography of North West University for providing equipment for soil sampling. The corresponding author would also like to thank iThemba LABS for the financial assistance that he received throughout the study period that made the research possible. The authors are also thankful to the Gold Mine authorities for their acceptance and co-operation to conduct the research within their premises. 
Author Contributions: Manny Mathuthu conceived and designed the experiment. He also did sample collection. Caspah Kamunda performed the experiment and did sample collection. He also analyzed the data and wrote the paper. Morgan Madhuku assisted in the design of the experiment and analysis of data.

Conflicts of Interest: The authors declare no conflict of interest.

\section{References}

1. Zakariya, N.I.; Kahn, M.T.E. Benefits and biological effects of ionizing radiation. Sch. Acad. J. Biosci. 2014, 2, 583-591.

2. WNA (World Nuclear Association). Radiation and Nuclear Energy. Available online: http://www.worldnuclear.org/info/inf30.html (accessed on 14 November 2014).

3. Nour, K.A.; Gabar, A.; Arabi, M. Natural radioactivity in farm soil and phosphate fertilizer and its environmental implications in qenagovernorate, Upper Egypt. J. Environ. Radioact. 2005, 84, 51-64.

4. USEPA (United States Environmental Protection Agency). Title 40 Code of Federal Regulations, Section 70.2. 2009. Available online: http://www.gpo.gov/fdsys/pkg/CFR-2009-title40-vol15/xml/CFR-2009-title40vol15-part70.xml (accessed on 20 October 2014).

5. Ziajahromi, S.; Khanizadeh, M.; Nejadkoorki, F. Using the RESRAD code to assess human exposure risk to ${ }^{226} \mathrm{Ra},{ }^{232} \mathrm{Th}$, and ${ }^{40} \mathrm{~K}$ in soil. Hum. Ecol. Risk Assess. An Int. J. 2014, 21. [CrossRef]

6. Winde, F.; Wade, P.; Van der Walt, I.J. Gold tailings as a source of waterborne uranium contamination of streams-the Koekemoerspruit (Klerksdorp goldfield, South Africa) as a case study-Part I: Uranium migration along the aqueous pathway. Water SA 2004, 30, 219-226. [CrossRef]

7. GDARD (Gauteng Department of Agriculture and Rural Development). Conceptual Study on Reclamation of Mine Residue Areas for Development Purposes; Final Report; Gauteng Provincial Government: Pretoria, South Africa, 2009.

8. NNR (National Nuclear Regulator). Radiological impacts of the mining activities to the public in the wonderfonteinspruit Catchment Area, South Africa. In The New Uranium Mining Boom; Report-TR-RRD-07-0006; NNR: Pretoria, South Africa, 2007.

9. Yu, C.; Zielen, A.J.; Cheng, J.J.; LePoire, D.J.; Gnanapragasam, E.; Kamboj, S.; Arnish, J.; Wallo III, A.; Williams, W.A.; Peterson, H. User's Manual for RESRAD, Version 6; ANL/EAD-4; Argonne National Laboratory: Lemont, IL, USA, 2001.

10. Kamunda, C.; Mathuthu, M.; Madhuku, M. Assessment of radiological hazards from gold mine tailings in Gauteng province, South Africa. Int. J. Environ. Res. Public Health 2016, 13, 138. [CrossRef] [PubMed]

11. McCarthy, T.; Rubridge, B. The Story of Earth and Life; Struik Publishers: Cape Town, South Africa, 2005; pp. 89-90, 102-107, 134-136.

12. DWAF (Department of Water Affairs and Forestry). Development of a Water Quality Management Plan for the Klip River Catchment. Phase 1: Situational Analysis, Draft Final Report; DWAF: Pretoria, South Africa, 1999.

13. IAEA (International Atomic Energy Agency). Measurement of Radionuclides in Food and the Environment; Technical Report Series No. 295; IAEA: Vienna, Austria, 1989.

14. Canberra Industries; Broad Energy Germanium Detectors (BEGe). Nuclear Measurement Solutions for Safety, Security and the Environment. Available online: http:/ / www.canberra.com (accessed on 13 October 2015).

15. David, J.; LePoire, J.J.; Arnish, T.R.; Klett, R.L.; Chen, S.Y. Pathways to Enhance Environmental Assessment Information Systems. Inf. Sci. J. 2004, 7, 117-128.

16. Eckerman, K.F.; Ryman, J.C. External Exposure to Radionuclides in Air, Water, and Soil: Exposure to Dose Coefficients for General Application; Based on the 1987 Federal Radiation Protection Guidance, EPA 402-R-93-081, Federal Guidance Report No. 12; Environmental Protection Agency, Office of Radiation and Indoor Air: Washington, DC, USA, 1993.

17. Smith, B. A community guide to estimating radiation doses from residual radioactive contamination. In Science for Democratic Action; Institute for Energy and Environmental Research: Takoma Park, MD, USA, 2008; Volume 15.

18. USDOE (United States Department of Energy). RESRAD-OFFSITE: A Tool for Evaluating Radiation Doses and Risks to Humans; Office of Nuclear Safety and Environment: Washington, DC, USA, 2007.

19. USDOE (United States Department of Energy). RESRAD-OFFSITE for Windows (Version 3.1): Nuclear Regulatory Commission, Environmental Science Division; Argonne National Laboratory: Argonne, IL, USA, 2013. 
20. Yu, C.; Loureiro, C.; Cheng, J.J. Data Collection Handbook to Support Modeling of the Impacts of Radioactive Material in Soil; ANL/EAIS-8; Argonne National Laboratory: Argonne, IL, USA, 1993.

21. NNR (National Nuclear Regulator). RG-002 Safety Assessment to Radiation Hazards to Members of the Public from NORM Activities; NNR: Pretoria, South Africa, 2013.

22. Hagemann, K. South Africa's Wind Potential; G\& Renewable Energies (Pty) Ltd.: Cape Town, South Africa, 2013.

23. USEPA (United States Environmental Protection Agency). Risk assessment guidance for superfund. In Human Health Evaluation Manual, (Part A) [R], Volume 1; EPA/540/1-89/002; Office of Emergency and Remedial Response: Washington, DC, USA, 1989.

(C) 2016 by the authors; licensee MDPI, Basel, Switzerland. This article is an open access article distributed under the terms and conditions of the Creative Commons Attribution (CC-BY) license (http://creativecommons.org/licenses/by/4.0/). 